\title{
THE CHANGING PATTERN OF ATTEMPTED SUICIDE IN EDINBURGH, 1962-67
}

\author{
BY \\ R. C. B. AITKEN, M.D., M.R.C.P.(Ed.), D.P.M. \\ DOROTHY BUGLASS, B.A., M.Phil. \\ NORMAN KREITMAN, M.D., D.P.M. \\ Medical Research Council Unit for Research on the Epidemiology of Psychiatric Illness \\ and \\ University Department of Psychiatry, Morningside Park, Edinburgh 10
}

A study of 'attempted suicide' in Edinburgh was undertaken by Kessel and McCulloch from mid1962 to mid-1963 and, in part, reported in the Milroy Lectures to the Royal College of Physicians (Kessel, 1965; McCulloch, 1965). Special interest in attempted suicide has continued in Edinburgh since that time. At the ward in the Royal Infirmary for the treatment of such cases, the Regional Poisoning Treatment Centre, admissions are seen not only by physicians but for the most part also by a psychiatrist. The practice in the city for all hospital-referred cases of attempted suicide to be admitted there has remained unchanged over the last five years, and it is therefore possible to compare the current prevalence of attempted suicide with that observed five years ago.

From the beginning of 1967 information on all admissions has been recorded systematically in a form suitable for transfer to punched cards. The data reported here are based on patients admitted to the Regional Poisoning Treatment Centre in 1967. No distinction is made between so-called gestures and serious attempts at suicide. Those who accidentally poisoned or injured themselves have been excluded from the present consideration. Six deaths occurred during the year and, as in the 1962/63 study, these patients have been excluded from our analysis in view of the known differences between the completed and attempted suicide populations.

As the aim of this report is to compare the prevalence of attempted suicide in the city population at different points in time, only patients admitted from an address in a defined census area-within the Edinburgh city boundaries-have been included. Twenty-two patients who met the residential criterion have been omitted because for miscellaneous reasons they were not assessed by the ward psychiatrist and hence information about them was incomplete: they represent $3.7 \%$ of the patient cohort.

The remaining 707 admissions form the cohort under review. These admissions represent 589 persons, the difference being due to those who had more than one admission during 1967. The ratio of persons to admissions is therefore $1: 1 \cdot 20$. For 1962/63 Kessel (op. cit.) and McCulloch (op. cit.) reported 514 admissions among 437 persons, a ratio of $1: 1 \cdot 18$. These ratios do not differ significantly.

\section{Prevalence of Attempted Suicide}

Rates for attempted suicide in Edinburgh have been calculated by sex and age for both events and individuals using the 1961 census for the 1962/63 data and the 1966 census for the 1967 data; these are illustrated in Figs. 1 to 4, and the crude rates are given in Table I. It can be seen from the diagrams that for females there has been an overall increase

\section{TABLE I}

CRUDE RATES PER 100,000 (AGE 15+) FOR ATTEMPTED SUICIDE, 1962/63 AND 1967, BY PERSONS AND ADMISSIONS

\begin{tabular}{|c|c|c|c|c|c|c|c|}
\hline \multirow{3}{*}{ Year } & \multicolumn{3}{|c|}{ Persons } & \multicolumn{4}{|c|}{ Admissions } \\
\hline & $\begin{array}{l}\text { No. of } \\
\text { Cases }\end{array}$ & \multicolumn{2}{|c|}{$\begin{array}{c}\text { Rates per } \\
100,000\end{array}$} & \multicolumn{2}{|c|}{$\begin{array}{l}\text { No. of } \\
\text { Cases }\end{array}$} & \multicolumn{2}{|c|}{$\begin{array}{c}\text { Rates per } \\
100,000\end{array}$} \\
\hline & $\mathbf{M} \quad \mathbf{F}$ & $\mathbf{M}$ & $\mathbf{F}$ & $\mathbf{M}$ & $\mathbf{F}$ & $\mathbf{M}$ & $\mathbf{F}$ \\
\hline $\begin{array}{l}1962 / 63 \\
1967\end{array}$ & $\begin{array}{ll}149 & 284 \\
228 & 354\end{array}$ & $\begin{array}{r}91 \cdot 8 \\
141 \cdot 9\end{array}$ & $\begin{array}{l}142 \cdot 2 \\
179 \cdot 2\end{array}$ & $\begin{array}{l}176 \\
291\end{array}$ & $\begin{array}{l}332 \\
415\end{array}$ & $\begin{array}{l}108 \cdot 5 \\
181 \cdot 1\end{array}$ & $\begin{array}{l}166 \cdot 3 \\
210 \cdot 0\end{array}$ \\
\hline $\begin{array}{l}\text { Significance } \\
\text { of difference }\end{array}$ & & $\begin{array}{l}P< \\
0.01\end{array}$ & $\begin{array}{l}P< \\
0.01\end{array}$ & & & $\begin{array}{l}P< \\
0.01\end{array}$ & $\begin{array}{l}P< \\
0.01\end{array}$ \\
\hline
\end{tabular}




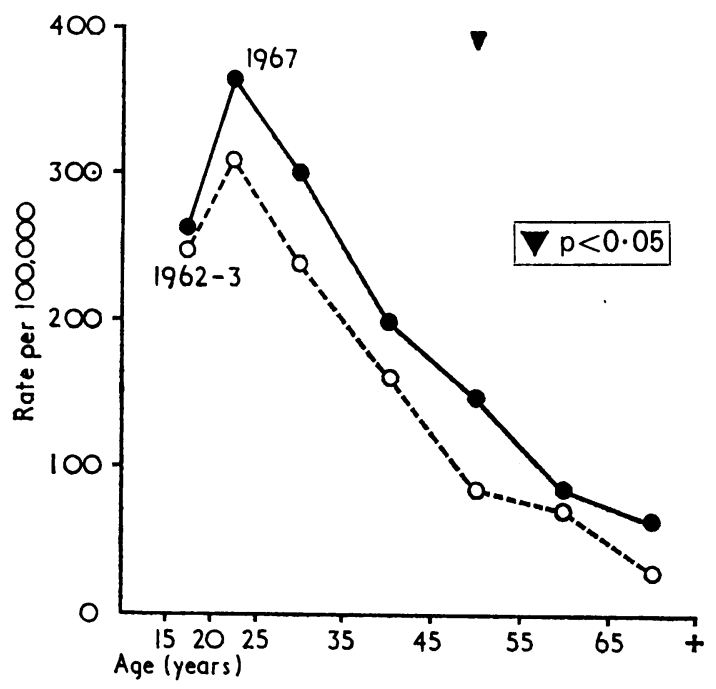

Fig. 1.-Female patients: Annual rates per 100,000 for attempted suicide, by age.

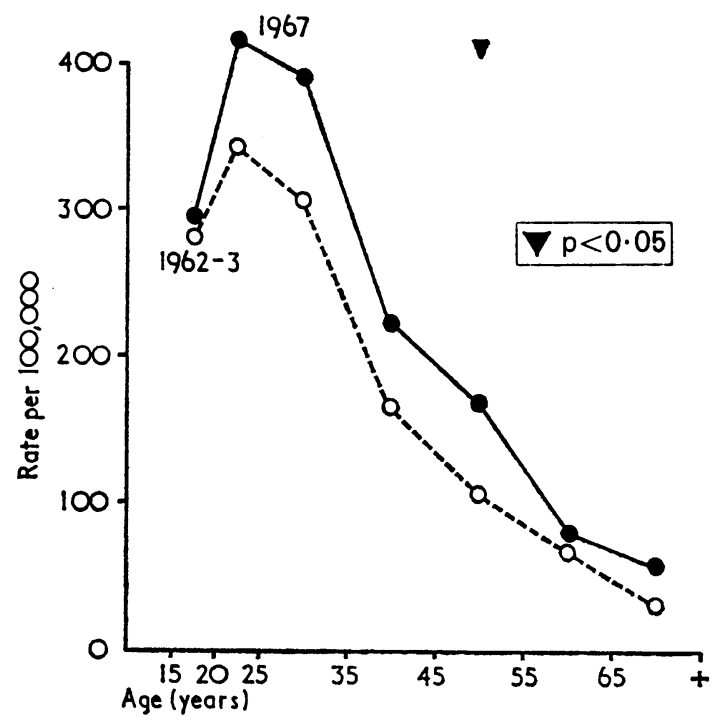

Fig. 2.-Female admissions: Annual rates per 100,000 for attempted suicide, by age.

in the rates for both persons and admissions. The form of the curve is similar in the two years under study. For males, however, there has been a dramatic increase in the rates for both persons and admissions in the younger age groups. The effect of this has been that, whereas in $1962 / 63$ the distributions for men and women were markedly different, in 1967 they were very similar. It can also be seen that the difference between rates for events and for individuals is principally accounted for by the younger age groups. Older people are relatively less often admitted more than once in the same year.

Marital Status

Rates by marital status and sex, for both persons

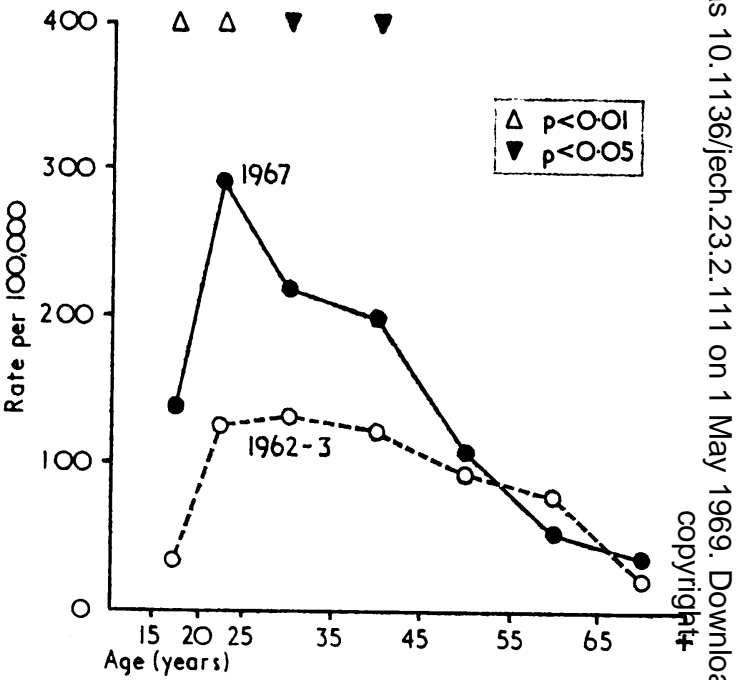

Fig. 3.-Male patients: Annual rates for 100,000 for attempted suicide, by age.

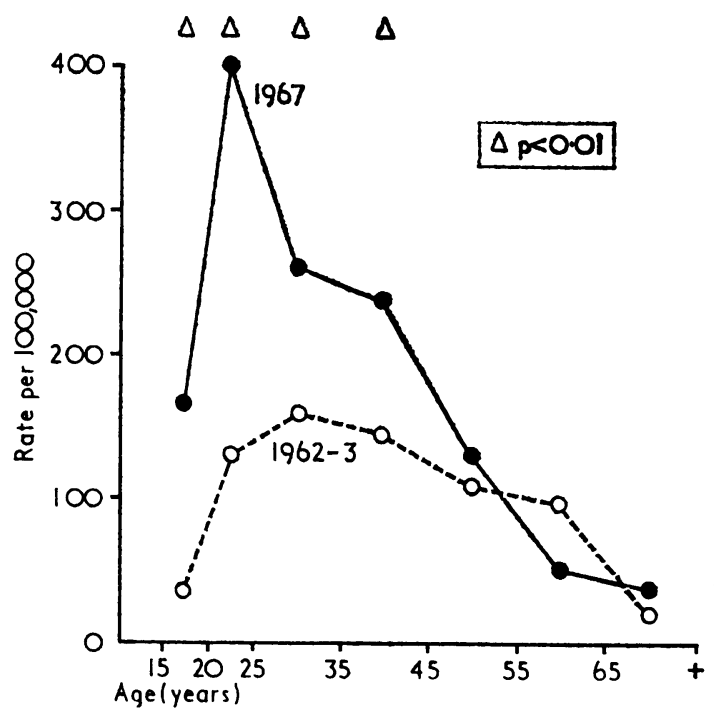

Fig. 4.-Male admissions: Annual rates per 100,000 for attempted suicide, by age. 
TABLE II

RATES FOR ATTEMPTED SUICIDE (PER 100,000) BY SEX, AGE, AND MARITAL STATUS

\begin{tabular}{|c|c|c|c|c|c|c|c|c|c|c|}
\hline \multirow{3}{*}{$\underset{\text { Status }}{\text { Marital }}$} & \multirow{3}{*}{ Age } & \multirow{3}{*}{ Year } & \multicolumn{4}{|c|}{ Persons } & \multicolumn{4}{|c|}{ Admistions } \\
\hline & & & \multicolumn{2}{|c|}{ No. of Cases } & \multicolumn{2}{|c|}{ Rate per 100,000} & \multicolumn{2}{|c|}{ No. of Cases } & \multicolumn{2}{|c|}{ Rate per 100,000} \\
\hline & & & $\mathbf{M}$ & $\mathbf{F}$ & $\mathbf{M}$ & $\mathbf{F}$ & $\mathbf{M}$ & $\mathbf{F}$ & $\mathbf{M}$ & $\mathbf{F}$ \\
\hline Single & $\begin{array}{l}15-34 \\
35+\end{array}$ & $\begin{array}{l}1962 / 63 \\
1967 \\
1962 / 63 \\
1967\end{array}$ & $\begin{array}{l}35 \\
73 \\
12 \\
17\end{array}$ & $\begin{array}{l}79 \\
92 \\
20 \\
15\end{array}$ & $\begin{array}{c}102 \cdot 7 \\
206 \cdot 3 \dagger \\
99 \cdot 1 \\
154 \cdot 3\end{array}$ & $\begin{array}{r}253.4 \\
284.7 \\
72.5 \\
59.6\end{array}$ & $\begin{array}{r}41 \\
100 \\
12 \\
26\end{array}$ & $\begin{array}{r}100 \\
116 \\
21 \\
15\end{array}$ & $\begin{array}{c}120 \cdot 3 \\
282.6 \dagger \\
99 \cdot 1 \\
235 \cdot 9 \dagger\end{array}$ & $\begin{array}{r}320.8 \\
359.0 \\
76.2 \\
59.6\end{array}$ \\
\hline Married & $\begin{array}{l}15-34 \\
35+\end{array}$ & $\begin{array}{l}1962 / 63 \\
1967 \\
1962 / 63 \\
1967\end{array}$ & $\begin{array}{l}22 \\
49 \\
58 \\
67\end{array}$ & $\begin{array}{r}80 \\
93 \\
77 \\
104\end{array}$ & $\begin{array}{c}88 \cdot 3 \\
204 \cdot 2 \dagger \\
69 \cdot 8 \\
81 \cdot 7\end{array}$ & $\begin{array}{c}250 \cdot 6 \\
304 \cdot 9 \\
98 \cdot 0 \\
134 \cdot 3\end{array}$ & $\begin{array}{l}26 \\
51 \\
71 \\
74\end{array}$ & $\begin{array}{r}91 \\
106 \\
87 \\
117\end{array}$ & $\begin{array}{c}104 \cdot 3 \\
212 \cdot 5 \dagger \\
85 \cdot 5 \\
90 \cdot 3\end{array}$ & $\begin{array}{l}285 \cdot 1 \\
347 \cdot 5 \\
110.7 \\
151 \cdot 1\end{array}$ \\
\hline Widowed & All & $\begin{array}{l}1962 / 63 \\
1967\end{array}$ & $\begin{array}{l}6 \\
8\end{array}$ & $\begin{array}{l}19 \\
33\end{array}$ & $\begin{array}{r}84 \cdot 0 \\
108 \cdot 3\end{array}$ & $\begin{array}{r}67 \cdot 3 \\
111 \cdot 1\end{array}$ & $\begin{array}{r}6 \\
10\end{array}$ & $\begin{array}{l}21 \\
36\end{array}$ & $\begin{array}{r}84 \cdot 0 \\
135 \cdot 3\end{array}$ & $\begin{array}{r}74 \cdot 3 \\
121 \cdot 2\end{array}$ \\
\hline Divorced & All & $\begin{array}{l}1962 / 63 \\
1967\end{array}$ & $\begin{array}{l}16 \\
11\end{array}$ & $\begin{array}{r}9 \\
14\end{array}$ & $\begin{array}{l}1,661 \cdot 5 \\
1,157 \cdot 9\end{array}$ & $\begin{array}{l}428 \cdot 6 \\
564 \cdot 5\end{array}$ & $\begin{array}{l}20 \\
13\end{array}$ & $\begin{array}{l}12 \\
19\end{array}$ & $\begin{array}{l}2,076 \cdot 8 \\
1,368 \cdot 4\end{array}$ & $\begin{array}{l}571 \cdot 4 \\
766 \cdot 1\end{array}$ \\
\hline
\end{tabular}

1967 rate differs significantly from $1962 / 63$ rate at $5 \%$ level of confidence.

+1967 rate differs significantly from $1962 / 63$ rate at $1 \%$ level of confidence.

and events, are shown in Table II. For men there have been significant increases in young individuals, both single and married, while for women the main increases have been in the older married group. On the whole, the Table reflects the age effects already noted and suggests that these are largely independent of civil state.

\section{CITY WARDS}

Kessel (op. cit.) drew attention to the marked variation in the crude rates of suicidal attempts between the various city wards of Edinburgh. We have standardized the ward rates for age and sex by determining the ratio of observed cases (patients) in each ward to the number which would be expected had each age-sex group in that ward behaved like the corresponding group among the population of Edinburgh as a whole. This has been done for both the original (1962/63) and the 1967 data. Table III shows that during the survey period there has been little overall change among city wards in their characteristic rates of attempted suicide. Thus there is no evidence for supposing that the increase in city rates is explicable by a disproportionate increase in attempted suicide in particular areas.

\section{Method of AtTempted Suicide}

In line with the earlier study we classified the admissions in 1967 by the principal agent used in the attempt. The distributions are given in Table IV from which it can be seen that the numbers of admissions attributable to self-injury, barbiturates, and carbon monoxide have fallen slightly between the two years. The use of 'poisons', substances such as lysol which were never intended to be ingested, account for only a very small fraction of the total in either year. Admissions due to overdosage with drugs readily available to the public, such as aspirin, have increased slightly but the most striking increase is in the use of 'other drugs'. These consist of non-barbiturate hypnotics, predominantly methaqualone + diphenhydramine (Mandrax), a variety of psychotropic drugs prescribed for anxiety and depression, and a miscellaneous group. Preliminary details on the various drugs used in 1967 have been published elsewhere (Aitken, Daly, Kreitman, Matthew, and Proudfoot, 1968).

TABLE III

STANDARDIZED MORBIDITY RATIOS OF CITY WARDS, 1962/63 AND 1967

\begin{tabular}{|c|c|c|c|c|}
\hline \multirow[b]{2}{*}{$\begin{array}{l}\text { City } \\
\text { Ward }\end{array}$} & \multicolumn{2}{|c|}{$1962 / 63$} & \multicolumn{2}{|c|}{1967} \\
\hline & $\begin{array}{l}\text { No. of } \\
\text { Cases }\end{array}$ & S.M.R. & $\begin{array}{l}\text { No. of } \\
\text { Cases }\end{array}$ & S.M.R. \\
\hline $\begin{array}{r}1 \\
2 \\
3 \\
4 \\
5 \\
6 \\
7 \\
8 \\
9 \\
10 \\
11 \\
12 \\
13 \\
14 \\
15 \\
16 \\
17 \\
18 \\
19 \\
20 \\
21 \\
22 \\
23\end{array}$ & $\begin{array}{r}41 \\
18 \\
22 \\
14 \\
35 \\
12 \\
8 \\
17 \\
15 \\
14 \\
8 \\
7 \\
28 \\
18 \\
22 \\
23 \\
25 \\
16 \\
22 \\
12 \\
13 \\
18 \\
25\end{array}$ & $\begin{array}{r}240 \\
139 \\
129 \\
64 \\
120 \\
77 \\
55 \\
71 \\
69 \\
80 \\
39 \\
35 \\
109 \\
75 \\
149 \\
141 \\
170 \\
111 \\
134 \\
71 \\
70 \\
74 \\
167\end{array}$ & $\begin{array}{l}51 \\
12 \\
26 \\
21 \\
44 \\
17 \\
18 \\
23 \\
19 \\
17 \\
21 \\
15 \\
45 \\
28 \\
19 \\
21 \\
28 \\
13 \\
28 \\
23 \\
22 \\
25 \\
45\end{array}$ & $\begin{array}{r}285 \\
96 \\
130 \\
64 \\
99 \\
83 \\
93 \\
63 \\
69 \\
75 \\
69 \\
43 \\
129 \\
87 \\
126 \\
99 \\
155 \\
66 \\
137 \\
106 \\
91 \\
80 \\
214\end{array}$ \\
\hline
\end{tabular}

Product moment correlation $1962 / 63$ and $1967, \mathrm{r}=+0.886$. 
TABLE IV

PRINCIPAL METHOD USED IN ATTEMPTED SUICIDE 1962/63 AND 1967: ALL AGES*

\begin{tabular}{|c|c|c|c|c|c|c|c|c|c|c|c|c|c|}
\hline & \multicolumn{4}{|c|}{ Males } & \multicolumn{4}{|c|}{ Females } & \multicolumn{4}{|c|}{ Total } & 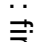 \\
\hline & \multicolumn{2}{|c|}{$1962 / 63$} & \multicolumn{2}{|r|}{1967} & \multicolumn{2}{|c|}{$1962 / 63$} & \multicolumn{2}{|c|}{1967} & \multicolumn{2}{|c|}{$1962 / 63$} & \multicolumn{2}{|c|}{1967} & $?$ \\
\hline & $\mathbf{N}$ & $\%$ & $\mathbf{N}$ & $\%$ & $\mathbf{N}$ & $\%$ & $\mathbf{N}$ & $\%$ & $\mathbf{N}$ & $\%$ & $\mathbf{N}$ & $\%$ & 듬 \\
\hline $\begin{array}{l}\text { Barbiturates } \\
\text { Salicylates } \\
\text { Other drugs } \\
\text { Coal gas } \\
\text { Poisons } \\
\text { Selfinjury } \\
\text { Other methods } \\
\text { Multiple methods } \\
\text { Not known }\end{array}$ & $\begin{array}{l}70 \\
16 \\
33 \\
10 \\
2 \\
19 \\
= \\
=\end{array}$ & $\begin{array}{r}47 \\
11 \\
22 \\
7 \\
1 \\
13 \\
= \\
=\end{array}$ & $\begin{array}{l}61 \\
33 \\
76 \\
12 \\
5 \\
12 \\
5 \\
17 \\
10\end{array}$ & $\begin{array}{r}26 \\
14 \\
-\quad 33 \\
5 \\
2 \\
5 \\
2 \\
7 \\
4\end{array}$ & $\begin{array}{r}143 \\
38 \\
51 \\
31 \\
3 \\
21 \\
= \\
=\end{array}$ & $\begin{array}{r}50 \\
13 \\
18 \\
11 \\
1 \\
7 \\
= \\
=\end{array}$ & $\begin{aligned} 125 \\
40 \\
135 \\
13 \\
4 \\
7 \\
12 \\
10 \\
12\end{aligned}$ & $\begin{array}{r}35 \\
11 \\
38 \\
4 \\
1 \\
2 \\
3 \\
3 \\
3\end{array}$ & $\begin{array}{r}213 \\
54 \\
84 \\
41 \\
5 \\
40 \\
= \\
=\end{array}$ & $\begin{array}{r}49 \\
12 \\
19 \\
9 \\
1 \\
11 \\
= \\
=\end{array}$ & $\begin{array}{r}186 \\
73 \\
211 \\
25 \\
9 \\
19 \\
17 \\
27 \\
22\end{array}$ & $\begin{array}{r}32 \\
12 \\
36 \\
4 \\
1 \\
3 \\
3 \\
5 \\
4\end{array}$ & 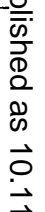 \\
\hline Total & 150 & (100) & 231 & $(100)$ & 287 & (100) & 358 & (100) & 437 & (100) & 589 & (100) & హు \\
\hline
\end{tabular}

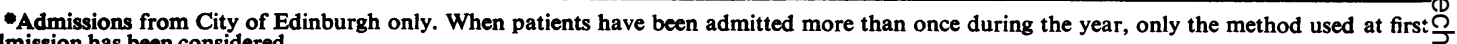
admission has been considered.

\section{Discussion}

In attempting to interpret the rise in the rates of admission for attempted suicide, a number of possibilities have to be considered. The first is whether there has been any change in the admission policy to the Regional Poisoning Treatment Centre. This can be firmly excluded. The ward has been under the charge of the same physician throughout the period under survey and policy has been consistent. The decision to admit is not influenced by consideration of the amount alleged to have been ingested; in every case in which that amount is believed to be more than a therapeutic dose prescribed for that individual, he or she is admitted, even if only for a few hours.

The second possibility is that the increased number of admissions may be due to changes in referral of patients from other hospitals to the Regional Poisoning Treatment Centre. This, too, is unlikely. In 1962/63 it was shown that about $90 \%$ of all the attempted suicides seen at hospitals in Edinburgh were referred to the Poisoning Treatment Centre at the Royal Infirmary (Kessel, McCullogh, Hendry, Leslie, Wallace and Webster, 1964), so that there is very little scope for any increase from this source.

The possibility that general practitioners might now be referring more patients to hospital, whom previously they may have treated in their homes, has been provisionally tested by an enquiry among a random sample of $\mathbf{1 7}$ general practitioners in the city. Of these, three suspected that they had altered their policy in this direction. Other evidence was sought by comparing the proportion of cases at the beginning and end of the five-year period who were assessed by the physicians as conscious or only drowsy on admission, on the argument that more ready referral by general practitioners would be reflected on a higher proportion of less toxic patients among those reaching hospital. It was found that? the relevant percentages for $1962 / 63$ and 1967 were $\overrightarrow{ }$ identical. Thus, there was no impressive evidence ${ }_{\circ}^{-}$

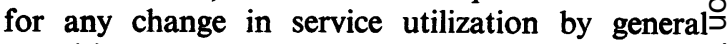
practitioners.

Finally, it is possible that the general public, becoming increasingly aware of the facilities pro-vided by the Poisoning Treatment Centre, are nowse referring themselves or their relatives directly to the.e hospital after a suicidal attempt. This conjecture? cannot readily be refuted, though there are somes grounds for thinking it unlikely.

All such arguments based on changing patterns of referral would have great difficulty in explaining $\mathbb{Q}$ the selective increase in young men. In view of all $\vec{F}$ these considerations, we conclude that there has been 3 a true rise in attempted suicide in Edinburgh for $\vec{F}$ most of the sex-age groups during the last five yearso and that this increase has been particularly marked in the young, and especially in men.

Two recent publications report rather similar:trends from other parts of the country. Evans 3 . (1967) describes a $65 \%$ increase in deliberate self- 8 poisoning in the Oxford region over the four years 1962-65 inclusive, although the age structure of theo increase is rather different from ours. From Cardiff, Graham and Hitchins (1967) also report a substan-o tial increase over a five-year period although its exact magnitude is not clear. In their data the maxi- $N$ mum increase among men was for those aged $15 \mathrm{~N}$ to 24 , as we have found, while the greatest increase N for women was at 55 to 64 .

The reasons for the changes over the last five years are by no means clear; we are more concerned at this stage to draw attention to the phenomenonos than to speculate on its cause. However, it might be ${ }_{D}^{-}$ worth noting that the tendency to parity of the sexes for attempted suicide may be connected with a. similar equalization in the sex-specific rates in 
completed suicide which has become increasingly evident over recent decades (Registrar General, 1964; McCulloch, Philip, and Carstairs, 1967). A more detailed comparison of trends in attempted suicide in relation to those for completed suicide might prove rewarding.

One other aspect of our data on which we would like to comment is the change in the principal agents employed. The two methods of main interest are the hypnotic and the psychotropic drugs. For barbiturates (although exactly comparable data for each of the years between 1963 and 1967 are unfortunately not available) we know that the total number of admissions for self-poisoning continued to rise until about 1965 since when it has dropped to the earlier level. The increased admissions for all hypnotics can largely be accounted for by poisoning with Mandrax. The psychotropic group, many of which have only become available in the period under review, have become increasingly popular as a method of self-poisoning, a trend also noted by Hershon (1968) in rural Shropshire. However, it is very much an open question whether the toxicological properties of these new substances render the treatment of overdosage any easier; tablet for tablet, overdosage with phenothiazines, monoaminoxidase inhibitors or Mandrax is as difficult to treat as that due to barbiturates (Matthew and Lawson, 1967).

It is reported that the number of prescriptions in England and Wales for hypnotics remained relatively constant between 1961 and 1966, while the number for psychotropic drugs more than doubled (C.H.S.C. Report, 1968). Although the need for limited and cautious prescribing is as imperative as ever, it should be pointed out that the increase in the number of prescriptions for the newer drugs, and in the number of attempted suicides, does not necessarily imply a causal connexion. Most people do not take an overdose only because the means are to hand. For the hypnotic and psychotropic drugs the relationship between need, demand, and supply is complex, but it seems clear that psychological distress may be a common factor in the request for medication and in suicidal behaviour. If this is so, the increasing frequency of attempted suicide implies that current efforts to alleviate psychological distress are inadequate.

\section{SUMMARY}

Data are presented on changes in the prevalence of attempted suicide in Edinburgh between 1962/63 and 1967. There has been an increase for both sexes in most age groups but especially for young men: changes specifically associated with civil state were not found. The use of psychotropic drugs and nonbarbiturate hypnotics in attempted suicide is now much more common.

We should like to express our appreciation to Professor G. M. Carstairs and to Dr. Henry Matthew, physicianin-charge of the Regional Poisoning Treatment Centre, for their encouragement to study these patients and for permission to publish the data. Thanks are also due to our colleagues who helped to document so carefully the clinical material, in particular Dr. R. J. Daly. The assistance of Miss Burns and Mrs. Kerr in card-punching the 1967 data is gratefully acknowledged. We are indebted to Professor Neil Kessel and Mr. Wallace McCulloch for making available to us the $1962 / 63$ data which we have extensively re-analysed.

\section{REFERENCES}

Aitken, R. C. B., Daly, R. J., Kreitman, N., Matthew, H., and Proudfoot, A. T. (1968). Coal gas and the brain. Brit. med. J., 1, 706.

Evans, J. G. (1967). Deliberate self-poisoning in the Oxford area. Brit. J. prev. soc. Med., 21, 97.

Graham, J. D. P., and Hrtchins, R. A. N. (1967). Acute poisoning and its prevention. Ibid., 21, 108.

HeRSHON, H. I. (1968). Attempted suicide in a largely rural area during an eight year period. Brit. J. psychiat., 114, 279.

Kessel, N. (1965). Self-poisoning. Brit. med. J., 2, 1265 and 1336.

-, McCulloch, W., Hendry, Joyce, Leslie, DoroTHY, WALlace, I., and Webster, R. (1964). Hospital management of attempted suicide in Edinburgh. Scot. med.J., 9, 333.

Matthew, H., and LAwson, A. A. H. (1967). The Treatment of Common Acute Poisoning. E. \& S. Livingstone, Edinburgh.

MCCulLOCH, J. W. (1965). The social consequences of acts of deliberate self-poisoning and self-injury. M.Sc. dissertation (unpublished). Edinburgh.

- Philip, A. E., and Carstairs, G. M. (1967). The ecology of suicidal behaviour. Brit. J. Psychiat., 113, 313.

Registrar General's Statistical Review of England and Wales for 1961 (1964). Part III. Commentary. H.M.S.O., London.

Report of the Joint Sub-Committe of the Standing Medical Advisory Committees of the Central Health Services Council and the Scottish Health Services Council (1968). Hospital Treatment of Acute Poisoning. 